\title{
Hicrî Illk Beş Asırda Tasavvufun Geçirdiği Süreçler
}

\section{The Processes of Sufism in the First Five Centuries of Hijri}

\author{
Merve Sağan \\ Marmara Üniversitesi, Türkiye \\ saganmerve@gmail.com
}

Geliş Tarihi: 24 Kasım 2019 Kabul Tarihi: 15 Mayıs 2020 Yayın Tarihi: 30 Temmuz 2020

Öz: Hz. Peygamber'in vefatından yaklaşık yüzyıl sonra "katı bir zühd hayatı" şeklinde belirginleşmeye başlayan tasavvuf, hicrî III. asra kadar "ilim" olarak tebarüz etmemişti. Hicrî III. asırdan itibaren sûfîlerin dinî konularla ilgili dile getirdikleri çeşitli görüşleri, başta fakîhler ve muhaddisler olmak üzere pek çok grubun tepkisine sebep olmuştur. Bunun neticesinde daha önceden tasavvufun ilmî değerini veya din ilimleri içerisindeki yerini tespit etmeye yönelmemiş sûfîler, tasavvufu, fıkıh-kelâm ve hadis geleneğine karşı bir "ilim" olarak savunmak durumunda kalmışlardır. Bunun sonucu olarak da sûfîler hicrî IV. asrın sonlarından itibaren Kur'ân ve hadis temelli bir çizgide eser telif etmeye ve düşüncelerini bu eserler vasıtası ile dile getirip savunmaya başlamışlardır. Bu bildiride bu süreç, yazarın hazırlamış olduğu yüksek lisans tezindeki değerlendirmeler üzerinden ortaya konulmaya çalışılacaktır.

Anahtar Kelimeler: Zühd, İlk Dönem Tasavvuf, Teşekkül Dönemi, Din İlimleri, Sûfi

Abstract: Nearly a century after the death of Prophet Muhammad, Sufism began to become evident in the form of a hayatı strict life of asceticism, century, as "science" had not tebarüz. Hijri III. The various views expressed by the Sufis on religious issues since the 19th century have caused the reaction of many groups, especially the jurists and muhaddis. As a result, the Sufis who had not previously attempted to determine the scientific value of Sufism or their place in religious sciences had to defend Sufism as a "science karşı against the tradition of fiqh-kalam and hadith. As a result of this, the Sufis were sent to Hijri IV. As of the end of the century, they began to write and defend their ideas through a line based on the Qur'an and hadith. In this paper, this process will be put forward through the evaluations in the master thesis prepared by the author.

Keywords: Zuhd, Sufism in the First Period, Formation Period, Religious Sciences, Sufi

\section{Giriş}

İslâm'ın fetihler sonucunda Hicaz'dan Doğu Akdeniz'e doğru yayıldığı süreçte, yeni toplumsal hayat ve yeni şehir değerleri ile yeni kültürlerle karşılaşılması sonucu, her anlamda kültürlerarası etkileşim zorunlu olarak ortaya çıkmıştı. Hicaz sonrası İslâm, 
Doğu Akdeniz'de kadim bir ilmî gelenek ile karşılaştı ve bu karşılaşma hem o yeni kültürle hem de kendi içindeki dinamiklerle birtakım çatışmalar yaşamasına sebep oldu. Bu noktada sorulması gereken soru şu: İslâm Doğu Akdeniz kültürü içerisine nasıl yerleşecekti? Bu süreçte İslâm'ın Hicaz'a özlem duyduğu muhakkaktır. Bu özlem sebebiyle de kendi değerlerini korumak adına savunmacı bir tavır takınması kaçınılmazdı. İslâm'ın bu bölgelere yerleşmesi ancak yeni bir bilgi anlayışı ve yeni düşünceler geliştirmesiyle mümkün olabildi. Yeni bir bilgi anlayışı geliştirmek, aynı zamanda böyle bir teşebbüse tepki gösterecek grupların da ortaya çıkmasına sebep olacaktı ki bu gruba biz "zahidler" diyeceğiz. Bu kimseler, "şehir"deki mevcut duruma karşı çıkan münzevi bireyler olarak bir çoğunluk oluşturmuş, dolayısıyla bir harekete dönüşmüştü. Zamanla eleştirel söylemlerini artıran bu bireyler daha fazla dikkat çekmeye ve cemaat haline gelmeye başladılar. Böylelikle genel zühd eğilimlerinden ayrışan, "şehirden uzaklaşan" diye tabir edebileceğimiz eleştirel bir zühd tipi ortaya çıkmış oldu. Şehirdekileri "kuralcı din" anlayışına sahip olmakla vasıflandıran bu grubun eleştirilerinin odaklandığı konular ise özellikle kesb-tevekkül ilişkisinde kesbe önem atfedilmesi, dinî ve toplumsal bozulma (bu sebeple sosyal hayattan uzaklaşmayı gaye edindiler), evliliğe temayül, bilim üretme kaygısıdır. Zühd içindeki bölünme alanlarını gösteren bu görüşler, bu grubu şehir hayatından kopardı. Bu sebeple insanlar tarafından kendilerine "miskin" isimlendirmesi yapıldı ve şehirde kalanlar ise "kuralcı din" anlayışının temsilcileri kabul edildiler. Bu kontrolsüz hareketler zamanla ibahi eğilimlere yöneldiler ve bunun etkisiyle kendi içinde bazı kırılmalar yaşadılar. Bu kırılmalar, tasavvuf anlayışı içerisinde "sahih ve batı" şeklinde ikili bir değerlendirmeyi zorunlu hale getirdi. Sahih ve batıl ayrımına giderek kendisini bu ayrıştırmadan kurtarmaya çalışan tasavvuf, bu durumun çözümü için kendine Sünnî ilimler arasında bir yer buldu. Bu süreç içerisinde muhatap ve muhaliflerini de belirleyen tasavvuf, muhaliflerinin görüşlerini eleştirerek Sünnî akide ve amel hayatına uygun bir anlayış geliş̧irmek istedi. Tasavvufun bu gayret içinde bulunduğu dönemi Ekrem Demirli "Sünnî Tasavvuf" olarak isimlendirmiştir. ${ }^{1}$

"Sünnî Tasavvuf"un belli başlı sorunlarına bakılacak olursak genel itibariye şu başlıklar çıkartılabilir:

1. Tasavvuf anlayışlarında "sahih-batıl" ayrımı

2. Tasavvufun ilim olma mücadelesi

\footnotetext{
I Özetle, zahitlik şu üç unsurla genel dindarlık anlayışından ve genel zühd eğilimlerinden ayrışaraka tasavvufa kaynaklık teşkil edecek bir mahiyet kazanmıştır: 1. Tevekkül-kesb, evlilik, toplumsal hayatta bulunma gibi konularda genel dindarlık anlayışından ayrışma, 2. Şehirden uzaklaşma, 3. Bilgi ve amel iliş̧isinde, bilginin ameli gerektirmesi düşüncesi (tezkiye ve tasfiye tavrını benimseyerek bilgiyi amelin karşısında zayıflatma) Ekrem Demirli, "Zahiri İlimlerin Otoritesi Karşısında Tasavvufun Meşruiyet Arayışı", İstanbul Üniversitesi Ilahiyat Fakültesi Dergisi, sayı:15, yıl:2007, s. 219-244, s. 10 vd., 26-27.
} 
3. Hz. Peygamber'den tevarüs edilegelen bir ilim oluşu/sürekliliki-devamlılık vurgusu

4. "Şeriat-Hakikat" ilişkisi sorunu (bilgi-eylem/iman/amel)

5. Nübüvvet-velayet ilişkisi sorunu

6. Dil sorunu: "Şatahat"

Hicrî III. asırdan itibaren sûfîlerin dinî konularla ilgili dile getirdikleri çeşitli görüşleri, başta fakîhler ve muhaddisler olmak üzere pek çok grubun tepkisine sebep olmuştur. Bunun neticesinde daha önceden tasavvufun ilmî değerini veya din ilimleri içerisindeki yerini tespit etmeye yönelmemiş sûfîler, tasavvufu, fıkıh-kelâm ve hadis geleneğine karşı bir "ilim" olarak savunmak durumunda kalmışlardır. Bu tavır, tasavvufun, bu ilimlerin ilim olma sürecinde "rey ve kıyas" olarak belirledikleri bilgi yöntemlerine karşı, ihmal ettikleri "ahlak" alanını sahiplenmesi ve kalbin tezkiye ve tasfiyesine dayalı bir yöntemi benimsemesi anlamına geliyordu. Bunun sonucu olarak da sûfîler hicrî IV. asrın sonlarından itibaren Kur'ân ve hadis temelli bir çizgide eser telif etmeye ve düşüncelerini bu eserler vasıtası ile dile getirip savunmaya başlamışlardır. Bu bağlamda Ebû Nasr esSerrâc (ö. 378/988), Ebû Bekir İshâk Kelâbâzî (ö. 380/990), Ebû Tâlib el-Mekkî (ö. 386/996), Abdülkerim Kuşeyrî (ö. 465/1072) ve Ali b. Osman Hücvîrî (ö. 465/1072) gibi müelliflerin yaşadığı ve genel kanı olması hasebiyle bizim de "erken dönem" olarak zikredeceğimiz hicrî IV. ve V. asırda önemle üzerinde durulan konuların başında, hadis, fıkıh ve kelâm gibi din ilimlerinin yanında tasavvufun da belli bir mevzuya (insandaki ahlaki değişimler), mesâile (haller ve makamlar), mebadi'e (insanı ahlaki yetkinliğe ulaştırmak) ve yönteme (istinbat/riyazet ve mücahede) sahip müdevven bir ilim olduğunu ortaya koymak gelmekteydi. Bunun yanı sıra sûfilerin hem kendi içlerinde yaşadıkları bazı anlaşmazlıklar (şatahat, sema', tevekkül gibi konular) hem de ibâhî ve ilhâdî grupların sûfîlere yönelttikleri eleştiriler, tasavvufun bir "ilim" olarak zapturabt altına alınıp diğer dinî ilimler arasındaki yerinin tayin edilmesini ve sünnî bir çerçevede ele alınmasını, böylelikle de bir ilim olarak tedvin edilmesini zorunlu hale getirmişti.2

Bu kapsamda tasavvufun iki muhatabının olduğu görülmektedir: 1. Dışta diğer din ilimleri, 2. İçte kendi mensupları. Bu bağlamda tasavvufun iki hedefinin olduğu söylenebilir:1. Kendi mensuplarına, tasavvufun hakikat anlayışının şeriat ile hiçbir şekilde çatışmadığını göstermek, 2. Fakih-kelam alimlerine tasavvufun da en az kendileri kadar "dinî bir ilim" meşruiyetine sahip olduğunu ifade etmek. Tasavvufun tedvin sürecinde yazılan tabakat kitaplarının da bu iki amaca matuf olarak kaleme alındığı söylenebilir. Bu noktada tasavvufun, muhaliflerince ibahilik ile itham edildiği de ifade

2 Demirli, a.g.e. 
edilmelidir. Bu sebeple öncelikle yapılması gereken, tasavvufun mahiyetinin öncelikle "müntesiplerine" ayrıntılı bir şekilde anlatılmasıydı. Daha sonra fıkıh-kelam alimlerine bu mahiyetin açıklanması gerekiyordu. ${ }^{3}$

Sorunlardan belki de en önemlisi olan şeriat-hakikat ilişkisinin sahih bir şekilde ortaya konulması gerekiyordu. ${ }^{4}$ ilk sûfiler arasında fıkıh formasyonlu kişiler vasıtasıyla, fıkıh bilginlerinin dile getirdiği "şeriat" ile tasavvufun ana konusu olan "hakikat" arasındaki çelişkiler giderilmeye çalışıldı. Tasavvufun bunu kendi özelliklerini dikkate alarak ve bunlardan feragat etmeden yapması elzemdi. Bu sebeple tasavvuf, kendisini diğer ilimlerden ayırt eden niteliklerini vurgulama yoluna gitti. Bu noktada kendisini konusu itibariyle "özel bir bilgi alanı" olarak tavsif eden tasavvuf, ayrıca bu ilmin "özel bir kabiliyet" gerektirdiğini de öne çıkardı. Bu noktadan hareketle tasavvuf, bu ilmin fıkıh gibi herkes için zorunlu ve bağlayıcı olmadığını da dolaylı olarak ifade etmiş oluyordu. ${ }^{5}$ Bu kabullerden hareketle şeriat-hakikat ilişkileri ve bu konuda ortaya çıkan problemler, sûfiler tarafından Ehl-i sünnet akaidi çizgisinde uzlaşmacı bir dil ve dengeli bir söylemle ortaya konulmaya ve çözülmeye çalışılmıştır. Bu konunun açıklığa kavuşturulmasında ise iman ve amelin gerekleri ile bilgi-eylem diğer bir ifadeyle iman-amel ilişskisinin tespit edilip ortaya konulması önem arz etmekteydi. Netice itibariyle de bu konu üzerinde önemle duran başta Serrâc olmak üzere Kelâbâzî, Ebû Tâlib el-Mekkî, Kuşeyrî ve Hücvîrî gibi erken dönem yazarlarının ortaya çıktığını söylemek mümkündür. Bu müelliflerden her biri, şeriat-hakikat bütünlüğü üzerinde vurgu yapmakta, bu bağlamda akıl-kalp, zâhir-bâtın, iman-İslâm, bilgi-eylem (ilim-amel) birlikteliğini merkeze alarak düşüncelerini bu minvalde ifade etmeye çalışmaktadır. Bu dönemde ele alınan şeriat-hakikat ilişskisi sorunu kapsamında, sûfîlerin, katı zühd anlayışına karşı amelin üstünlüğünü savunmak adına tezyif ettikleri bilgi anlayışıyla tekrar ve daha sağlam irtibat kurmalarını zorunlu hale gelmiş oldu. Bu dönemde tasavvufun alan, konu, yöntem ve mahiyetinin belirlenmesine yönelik gösterilen çabalar, bu cihetten bakıldığında daha fazla önem arz etmektedir. Yöntemin ve ilkelerin bu çerçevede belirlenmesinden sonra bu kaidelere uymayan konular "şatahat" olarak ifade edilerek ne tam kabul gördü ne de tam bir redde maruz kaldı, tabiri caizse tam anlamıyla muallakta bırakıldı. ${ }^{6}$

\footnotetext{
3 Demirli, a.g.e., s. 222.

${ }^{4}$ Bu konu hakkında Hacı Bayram Başer'in önemli bir çalışması mevcuttur. Bk. Hacı Bayram Başer, Şeriat ve Hakikat: Tasavvufun Teşekkül Süreci, İstanbul, Klasik Yay., 2017.

${ }^{5}$ Demirli, a.g.e, s. 225.

6 Demirli, "Tasavvuf Araştırmalarında Dönemlendirme Sorunu: Din Bilimleri ile Metafizik Arasında Tasavvufun İlim Olma Mücadelesi”, Nazariyat: İs/âm Felsefe ve Bilim Tarihi Araştırmaları Dergisi, sayı: 2/4, yıl: Nisan 2016, s. 1-29., s. 14,18.
} 
Tasavvufun bir ilim olarak tedvin edilme sürecini "eleştiri" "kriz" ve "uzlaşı" olmak üzere üç dönem şeklinde ele alırsak bu müelliflerin, özellikle fıkıh-tasavvuf ilmi arasında bir tür "uzlaşı" sağlamaya çalıştıklarını, bu sebeple kendilerinin "uzlaşı dönemi müellifleri" olarak kabul edilebileceğini söylemek mümkündür. Ayrıca bu müelliflerin kendilerinden bir asır önce yaşamış Bayezid-i Bestâmî (ö. 261/875), Sehl-i Tüsterî (ö. 283/896), Cüneyd-i Bağdâdi (ö. 297/909) gibi büyük imam/kurucu sûfîlerin "şârihleri" olarak da kabul edildiklerini belirtmek gerekir. Dolayısıyla erken dönem müelliflerinin bir taraftan tasavvufu bir "din ilmi" olarak ortaya koymaya çalışırken diğer taraftan kurucu müelliflerin görüşlerini şerh etmeyi amaç edindikleri söylenebilir.

Kendinî "ilim” olarak görmek demek, mevzu, mesâil, mebadi ve yöntemini belirlemeyi elzem kıldığı gibi aynı zamanda muhatap ve muhaliflerini de belirlemeyi gerektirir. Bu dönemde tasavvufun büyük muhalifi, ibahi eğilim ile şeriat ilimlerini küçümseyen taşır sahipleri ile Batınilerdir. İç muhaliflerden birisi de insanın özgürlük ve iradesi üzerine görüşler serdeden Muteziledir.

Bir başka ayrışma noktası ise velayet konusunda görülmektedir. Tasavvuf bu sorunu, tüm inananların "velilik" niteliğinde müşterek olduğu fikrini öne süren Mutezile ile bu vasfı sadece "imam" otoritesine hasreden Şia arasında bir noktada ve en önemlisi Ehl-i sünnet akaidine paralel şekilde çözmeye çalıştı. "Velilik" ten bahsetmek, tasavvuf için bağlayıcı bir otoriteden bahsetmek demekti. Bu bağlayıcı otorite düşüncesi, tasavvufun anlam ve mahiyetini ortaya koyma sürecinde, kendisine özel bir alan ve anlam atfetmesinin sonuçlarından sadece biridir. Kendisine atfettiği "seçkincilik", "özel bir bilgi alanı" oluşunun ve "özel bir kabiliyet" gerektirdiğinin bir başka ifadesi olarak telakki edilebilir. Tasavvuftaki velayet düşüncesinin açıklığa kavuşturulması, nübüvvet ile ilişkisinin belirlenmesi noktasında da önem arz etmektedir. Nübüvvet müessesesine zarar gelmeden velilik otoritesine tasavvufta nasıl yer verilebilir? Sûfiler bu soruya çözüm bulabilmek adına, öncelikle nübüvvet-velilik ile mucize-keramet arasındaki farkları ortaya koymuşlardır. Ortaya konulan düşüncelerin genel çerçevesini ise nübüvvet ile velayet arasında temelde fark olmadığı, farkın misyon ve vizyona bağlı olarak ortaya çıktığı düşüncesi oluşturmaktadır. Nitekim Serrâc'a bakıldığında keramet ve mucize arasında özde bir fark yoktur, fark misyon ve vizyona bağlı olarak ortaya çıkar. Tasavvuf içinde velilerin otoritesi konusunda Serrac ve Kuşeyrî, velinin yanılma ve hata meselesinin tasavvuf içinde kendi otoritelerince açıklığa kavuşturulması gerektiğini ifade eder. Böylece veli ve şeyhlerin masum olmadıkları bizzat tasavvuf içindeki sûfilerce itiraf edilmiş olmaktadır. Bununla birlikte onların mahfuz oldukları üzerinde durulmuştur. 
Onlar için mahfuzluk, "günahta ısrar etmemek" ile ilgili olarak anlaşılmalıdır. ${ }^{7}$ Velayet konusunda ortaya çıkan bir başka soru ise şudur: Velayette bütün müminler ortak mıdır? Bu soru karşısında sûfilerin tavrı, Ehl-i sünnet itikadına zarar vermeden, kendilerinin özel bir alana sahip olduğunu da vurgulayacak şekilde bir teori oluşturma yönünde oldu.

Şimdi Sünnî tasavvufun önde gelen müelliflerinin temel olarak odaklandığı konulara değinmek yerinde olacaktır. Ama -özellikle Serrâc'ın önemle vurguladığı- tasavvufun alanı ve yöntemi olan bir ilim olarak kabul edilmesinin, tasavvuf klasikleri olarak adlandırabileceğimiz eserlerdeki ortak tavır olduğunu belirtmek gerekir. Serrâc, ilimler arası ilişkileri iki ana nokta etrafında ele alır. Bunlardan ilki tasavvuf, hadis, fıkıh, kelâm gibi bir din ilmidir ve alanı, konusu, sınırları ve yöntemi olduğu gibi belli bir yetki alanına da sahiptir. Bu bağlamda Serrâc, her ilmin kendi alanında yetkin olduğunu kabul etmekte, bir din ilmi olarak tasavvufa da aynı yetkinliğin tanınması gerektiğini düşünmektedir. İkinci olarak ise sûfîler, dinî emirlerin yükümlülüğünü kabul etmeyen sapkın gruplarla aynıymış gibi veya bid'at türü bir tavır olarak değerlendirilmemelidir. Serrâc ve Mekkî'ye göre sûfîleri bu gruplardan ayıran en önemli özellik, bâtın ilminin yanı sıra zâhir ilim ve âlimlerin uygulamalarını da dikkate almaları, zâhir amellere önem verip uygulamaları, bâtın ilmine ancak bu yolla ulaşabileceklerine inanmalarıdır. Dolayısıyla genelde tüm erken dönem sûfilerinde özel olarak ise Serrâc ve Mekkî'de ilm-i zâhir, sûfînin tasavvuf yoluna girmeden önce öğrenmek zorunda olduğu bilimsel alan olarak telakki edilmektedir. Bununla birlikte tasavvuf, konusu ve gayesinin Allah olması itibariyle diğer ilimlerin kendisine yöneldiği, tüm ilimlerin özü ve nihâî noktasını oluşturan bir ilimdir. ${ }^{8}$

Kelâbâzî için öncelikli sorun, bir ilim olarak tasavvufun, Ehl-i sünnet bilginleri tarafından sınırları çizilmiş inanç ilkelerinin dışına çıkmadığının ortaya konulmasıydı. Kelâbâzî etTa'arruf ta tasavvufun içerisinde bir "bozulma" yaşandığını belirtmekte ve bu bozulmayla ve buna sebep olanlarla mücadele edilmesi gerektiğini düşünmektedir. Buna ek olarak sözde sûfîler ile hakîkî sûfîler arasında ayrım yapılması gerektiğini savunan Kelâbâzî, aynı zamanda tasavvufun önemli şahsiyetlerinin sözlerini ele alarak hakîkî tasavvufun ne olduğunu ortaya koymaya çalışmakta ve bu bağlamda sözde sûfîleri eleştirmektedir. ${ }^{9}$ Mekkî'nin bilgi anlayışını ise hadis, fıkıh ve kelâm gibi din ilimlerine ve bid'at olarak vasfettiği ilimlere yönelttiği eleştirilerden hareketle anlamamız mümkündür. Onun

\footnotetext{
7 Demirli, "Zahiri İlimlerin Otoritesi Karşısında Tasavvufun Meşruiyet Arayışı”, s. 238-241.

8 Merve Sağan, "Ebû Tâlib el-Mekkî'nin (ö. 386/996) Düşüncesinde Dinî Illimlerin Gelişimi ve Tasavvuf", Yüksek Lisans Tezi, Yalova Üniversitesi Sosyal Bilimler Enstitüsü, 2018. s. 25.26.

${ }^{9}$ Kelâbâzî, et-Ta‘arruf, s. 19-21; a. mlf., Doğuş Devrinde Tasavvuf, s. 49-52. (Mukaddime) Serrâc, Kelâbâzî ve Mekkî'nin yanı sıra Muhâsibî, Hücvîrî, Kuşeyrî ve Gazzâlî de sahte sûfîleri ve davranışlarını eleştirmişlerdir. Sağan, "Ebû Tâlib el-Mekkî’nin (ö. 386/996) Düşüncesinde Dinî İlimlerin Gelişimi ve Tasavvuf”, s. 31.
} 
ilimlerle meşgul olanlara yönelttiği bu eleştirilerindeki temel nokta, bu ilimlerin bilgiyi konu edinîrken "amel” yönünü zayıf bırakmalarıdır. Dolayısıyla Mekkî'nin tasavvuf anlayışı, âdâb ve ahlâk üzerine kurulmuştur. Onun yakin ilmine dair bahsettiği konulara dikkat edildiğinde bunların daha çok amele dair konularla ilgili olduğu müşahede edilmiştir. Dolayısıyla Mekkî, bilgi-eylem bütünlüğünü vurgulayan bir müellif olarak karşımıza çıkar. Sadece bilgi-amel bütünlüğü ile kalmaz, bu ikili arasındaki ilişkisi şeriat-hakikat, zahir-batın arasındaki ilişkiler ağına da uygular ve tüm bunları insanın ahlâki terakki sürecine yaptığı katkılar bağlamında ele alır.

Onun din ilimlerine yönelik eleştirilerinin temelini, ahlâk ve sosyal ilişkilerde $\mathrm{Hz}$. Peygamber'den sonra, bilgi, ahlâk ve sosyal ilişkilerde kademeli olarak bir "bozulma" yaşandığı düşüncesi oluşturmaktadır. Bu sebeple din ilimlerinde gerçekleşen bozulma, külli bir bozulmanın sadece bir bölümünü ifade etmektedir. Mekkî, Hz. Peygamber'den bu yana gerçekleşen bu bozulmanın din ilimlerine "bid'at" olarak tebellür ettiğini, bahsi geçen bozulmanın nedeninin ise bilgi noktasında "amel" boyutunun ihmal edilmesi olduğunu düşünmektedir. ${ }^{10}$ Mekkî'nin düşüncesinde bid'at, sadece "sonradan ortaya çıkan şeyleri” değil aynı zamanda "bozulmayı" da kapsayan bir kavram olarak tebarüz eder. Bu açıdan "bid'at" kavramı, Mekkî'nin bilgi anlayışında merkezî bir rol üstlenmektedir. ${ }^{11}$

Kuşeyrî ise bu bağlamda, tasavvufu bir din ilmi yapan şeyin, belli ıstılahlara sahip olması olduğunu dile getirmekteydi. Gerçek sûfîlerin İslâm'daki yerine ve önemine değinerek eserine başlayan Kuşeyrî ise, bozulma bağlamında hakîkî sûfîlerin sayılarının gittikçe azaldığını söylemekte, sözde sûfîlerin dinî hükümleri hafife alıp ibadetleri önemsemediklerini ve helal ile haram arasında fark görmeyerek bedenî hazlara yönelmelerini eleştirmektedir. ${ }^{12}$ Buradan hareketle Kuşeyrî de tasavvufun sünnî çizgi ile mutabık olduğunu, sûfîlerin, gerek mustasvifler gerekse dinî hükümleri hafife alan ibâhîlik gibi sapkın gruplardan rahatsız olduğunu ve tasavvuf ve ehlinin bu gruplardan ayrı düşünülerek amele diğer ilimlerden daha fazla önem verdiğini ortaya koymak istemiştir. Ayrıca Kuşeyrî'nin yaşadığı dönemde tasavvuf bir "zındıklık, Kur'ân ve hadisten uzaklaşma" olarak kabul görmekteydi. Bunun sebebi ise mustasviflerle birlikte bazı Şiî akideleri ve batıl inançların tasavvuf konularına karıştırılmış olmasıdır. Dolayısıyla Kuşeyrî'nin hedef kitlesini mustasvifler ve sapkın gruplar ile Mu'tezile ve Şiî

\footnotetext{
10 Sağan, “Ebû Tâlib el-Mekkî̀nin (ö. 386/996) Düşüncesinde Dinî Illimlerin Gelişimi ve Tasavvuf”, s. 23.

11 Konuyla irtibatlı olarak bk. Demirli, "Tasavvuf Araştırmalarında Dönemlendirme Sorunu: Din Bilimleri ile Metafizik Arasında Tasavvufun İlim Olma Mücadelesi”, s. 3-4.

12 Kuşeyrî, er-Risâle, s. 21-24; a. mlf., Kuşeyrî Risâlesi, s. 79-82. (mukaddime kısmı).
} 
akidelerinin oluşturduğu söylenebilir. ${ }^{13}$ Kuşeyrî’nin sahte sûfîlere ve sapkın gruplara bu kadar sert tepki göstermesi, erken dönem sûfîlerinin şeriata sımsıkı sarılıp sünnete ittibâda kusur etmemeye çalıştıklarını gözler önüne sermektedir. ${ }^{14}$

Hücvîrî̀nin ise diğerlerini aksine biraz daha nazarî tartışmalara girerek sûfilerin ve bir din ilmi olan tasavvufun, bilginin imkanını reddeden bazı sapkın görüşlerle karıştırılmasına tepki gösterdiği söylenebilir. Müelliflerin bu çabaları, Hz. Peygamber'den bu yana zühd hareketi olarak devam eden tasavvufun, özellikle hicrî II. ve III. asırda döneme hakim olan ilmî tasnif ve tanzim girişimlerinin etkisinde kalarak bir tür "sistematikleşme"ye doğru evrilmesi olarak algılanmalıdır.

Hücvîrî de bozulma ile ilgili olarak Keşfü'l-mahcûb'un mukaddimesinde tasavvuf ilminin zamanla yok olup gittiğini, insanların bu ilmin künhüne vakıf olma gayesinde olmayıp sadece ibaresi ile yetindiklerini zikretmekte, işin artık tahkik değil taklit boyutuna ulaştığından yakınmaktadır. Bu noktada sadece avamı ve müddeileri (sahte sûfîleri) değil aynı zamanda havastan bazılarını da eleştiriye tabi tutmakta, böylece tasavvufa Muhâsibî'nin öncülük ettiği- bir iç eleştiri yapmaktadır. Bu grupların yanı sıra heva ve hevesine "şeriat" adını vererek dilediklerini yapanlardan ve bunlar olurken bir köşeye çekilen mâna ehlinden de bahis açmaktadır. Hücvîrî aynı zamanda "mülhidler" diyerek kendilerinden bahsettiği sahte sûfîlerin söz ve düşünceleri sebebiyle halkın bu kimselerden duyduklarını tasavvuf ilmi zannedip bu ilim hakkında kötü bir yargıya ulaştıklarını dile getirmekte, insanların bu zanları sebebiyle hak ile batılı ayırt etmekten aciz kaldıklarını ifade etmektedir. Sûfîler ile mustasvife arasında ne gibi farklar olduğunu, sûfîlerin hangi davranışlar ile yanlış olarak vasfedildiğini de belirtmektedir. ${ }^{15}$ Hücvîrî'nin bu bozulmalar kapsamında pek çok yerde ibâhîleri eleştirdiği görülmektedir. Merdûd olarak değerlendirdiği fırkalar Hülmâniye ve Hallâciye'nin hataya düştükleri noktanın, ruhun varlığı, niteliği ve vasıfları hususunda olduğunu, zâhirîlerin, bu iki fırkanın ruh hakkındaki yanlış kanaatlerinin sûfîlerin görüşü olarak telakki ettiklerini ve bu konuda hataya düştüklerini belirtmekte; bu şekilde hem tasavvufa bir iç eleştiri yapmakta hem de tasavvuf ve ehli hakkında oluşmuş yanlış kanaatleri tashih etmeye

\footnotetext{
13 Kuşeyrî'nin bu çabalarını kendisinden sonra Hücvîrî ve Gazzâlî devam ettirmiş, Gazzâlî ihya'ında sünnî tasavvufa asıl kimliğini kazandırmış, tasavvufun tam anlamda tanzim ve tesisini gerçekleştirmiştir. Kadir Özköse, "Klasiklerimiz III: er-Risâle" (İmam Abdülkerim Kuşeyrî, ö. 465/1072), Tasavvuf IIImî ve Akademik Araştırma Dergisi, sayı: 4; yıl: Eylül 2000, s. 202.

14 Sağan, "Ebû Tâlib el-Mekkî̀nin (ö. 386/996) Düşüncesinde Dinî Illimlerin Gelişimi ve Tasavvuf”, s. 31.

15 Hücvîrî, Keşfü'l-mahcûb, s. 191-201, 209-213, 294-295; a. mlf., Hakikat Bilgisi, s. 72-73, 81-84, 152153; Sağan, “Ebû Tâlib el-Mekkî’nin (ö. 386/996) Düşüncesinde Dinî illimlerin Gelişimi ve Tasavvuf”, s. 32.
} 
çalışmaktadır. ${ }^{16}$ Aynı şekilde akıl ve istidlâlle Allah hakkında bilgi sahibi olma konusuna temas ederek Mu'tezile'yi, Brahmanizm'den geldiğini söyleyerek de ilhamcıları eleştiriye tabi tutmuştur. Ona göre bu zümreler akıl ve istidlâli mârifetin illeti kabul etme noktasında hataya düşmüşlerdir. Halbuki bunlar mârifetin vasıta ve sebepleridir. Yine Seneviye, Tabiatçılar, Felekiyye, Mu'tezile, Cebriye ve Dehriyye'nin tevhid anlayışlarını eleştirmiştir. ${ }^{17}$

İlim-amel bütünlüğü ile şeriat-hakikat bütünlüğünün bağlantılı olarak telakki edilmesi, ilk dönem sûfîlerinin teksif ettiği konulardan biridir. Sözgelimi sûfîlere göre hakikat şeriatın örtüsüyle gizlenmiş bâtınî mâna iken şeriat uzuvlarla ilgili olan zâhirî davranışları kapsamaktadır. Öyleyse şeriat-hakikat bütünlüğünün, diğer sûfîler gibi Mekkî’nin de düşünce yapısında temel taşlardan biri olduğunu söylemek mümkündür. Bâtın ilmi ile zâhir ilmi arasındaki irtibatı gösterebilmek adına Mekkî, şeriat-hakikat bütünlüğüne değinerek sûfîlerin ve de tasavvufun gerek zâhirde gerekse bâtında şeriata aykırı hareket etmediğini vurgulamaktadır. ${ }^{18}$ Ondan önce Serrâc'ın da zâhir ile bâtın ilmini ele alırken şeriat-hakikat bütünlüğünü göz önünde bulundurduğu, tasavvufun hakikati savunurken, dinî yükümlülükleri hafife alan ibâhîler gibi şeriata aykırı hareket etmediğini de özellikle belirttiği görülmektedir. ${ }^{19}$ Kuşeyrî ise tasavvufu zühdden tasavvufa, amelden mârifete, ibadetten irfana, şeriattan hakikate geçiş şeklinde ele almaktadır. Müteşerri bir âlim olan Kuşeyrî, zâhir ve bâtın ilimlerine hakimdir. Bu noktadan hareketle onun tasavvuf anlayışını zâhir ile bâtını, şeriatla hakikati birlikte ele almak üzerine bina ettiğini söylemek mümkündür. Bununla birlikte, onun tasavvufun mârifet yönünden ziyade amel cihetine ağırlık verdiği görülmektedir. Hücvîrî'nin de öncelikle şeriat ve hakikatin ne olduğunu açıklayarak tasavvuf anlayışını şeriat-hakikat bütünlüğü üzerine bina ettiği görülmektedir. ${ }^{20}$

Tüm erken dönem sûfîlerinin, dönemin din, ahlâk, ibadet hayatı ve ilim anlayışına ciddi eleştirilerde bulunduklarını söylemek mümkündür. Onların bu eleştirel tavrı sergilemelerinin temelde iki sebebi olduğu düşünülebilir. Birincisi, tasavvufun hem kendi içindeki kişilere

16 Hücvîrî, Keşfü'l-mahcûb, s. 453, 501-508, 529; a. mlf., Hakikat Bilgisi, s. 280, 322-327, 351-352; Sağan, "Ebû Tâlib el-Mekkî’nin (ö. 386/996) Düşüncesinde Dinî ilimlerin Gelişimi ve Tasavvuf", s. 32.

17 Hücvîrî, Keşfü'l-mahcûb, s. 509-518 , 519-523, 529; a. mlf., Hakikat Bilgisi, s. 331-341, 342-345, 352; Sağan, “Ebû Tâlib el-Mekkî̀nin (ö. 386/996) Düşüncesinde Dinî Illimlerin Gelişimi ve Tasavvuf”, s. 32.

18 Mekkî, Kûtü'l-kulûb, I: 335-336; a. mlf., Kalplerin Azığı, II: 115.

19 Serrâc, el-Lüma', s. 25; a. mlf., is/âm Tasavvufu, s. 22-23.

20 Özköse, "Klasiklerimiz III: er-Risale", s. 203; Hücvîrî, Keşfü’l-mahcûb, s. 626-627; a. mlf., Hakikat Bilgisi, s. 440-441; Sağan, "Ebû Tâlib el-Mekkî’nin (ö. 386/996) Düşüncesinde Dinî Illimlerin Gelişimi ve Tasavvuf”, s. 36. 
hem de fıkıh, hadis, kelâm gibi diğer din ilimlerine karşı kendisinin de bir "din ilmi" olduğunu dile getirmek; ikincisi ise sûfîlerin yoğun riyâzet ve mücâhede yöntemini benimsediğini göstermek suretiyle hem ibâhî akımlara karşı çıkarak tasavvufun amele yaptığı vurgu bakımından bu gruplardan ayrı düşünülmesini gerektiğini vurgulamak hem de tasavvuf için bir iç eleştiri mekanizması geliştirmeye yönelmektir.

Bu noktada ilk olarak Serrâc, bilgi anlayışını genel itibariyle her ilmin belirli bir mevzusu, mesâili, sınır ve yöntemi bulunduğu kabulü üzerine bina etmiştir. Ona göre her ilim, kendi alanını oluşturduğu gibi, alanıyla ilgili meseleleri çözmede de öncelikli bir otoriteye sahiptir. Tasavvuf da din ilimlerinden biridir ve diğer din ilimlerinin dinî kaynakları kendi yöntemleri ile yorumlayabildikleri gibi ana kaynakları Kur'ân ve sünnet olan tasavvuf ilmi de Kur'ân ve sünneti "işâret" ve "istinbat" yöntemiyle yorumlama yetkisine sahiptir. ${ }^{21}$ Yine sûfîler ile ibâhîlik arasında kesin bir ayrım yapılmalıdır. Zira ibâhîlik, belli bir mertebeden sonra dinî sorumlulukların kalktığı düşüncesinde iken tasavvufta gaye, ibadetlere yoğunlaşmak suretiyle ahlâkî terakkiyi gerçekleştirip kişinin yetkinleşmesini sağlamaktır. Bu açıdan bakıldığında Serrâc'ın bir "din ilmi” olarak kabul ettiği tasavvuf, esas itibariyle iki gruba karşı mücadele vermektedir. Bunlardan ilki diğer din ilimlerin âlimleridir ve Serrâc bu kişilere karşı tasavvufun da bir din ilmi olduğunu ortaya koymaya çalışmaktadır. Diğeri ise sapkın görüşleri nedeniyle ibâhî gruplardır ve tasavvufun bu grupların aksine amele ziyadesiyle önem verdiğini her fırsatta dile getirmek, tasavvufun mâhiyetinin ortaya konulması açısından önem arz etmektedir.

Serrâc, kelâmın "bid'at ve dalâlet ehline karşı dinî savunup deliller ortaya koymak için geliştirilen kıyas, nazar ve cedel ilmi" olduğunu belirtmiştir. ${ }^{22}$ Serrâc şatahat hakkında söz söylemede ise öncelikli yetkinin tasavvuf ehline ait olabileceği üzerinde durur. Bu konuyla ilgili olarak ayrıca şatahatın henüz yolun başında olanların bir hali ve gerçekte bunun tasavvufta istisnai bir durum olduğunu özellikle vurgulamaktadır. Serrâc böylece hem sûfîlerin tasavvufla ilgili konularda fikir beyan etme yetkisine sahip olduklarını dile getirmekte hem de tasavvufa bir nevi iç eleştiri yönelterek tasavvufun sınırlarını çizmektedir. 23

\footnotetext{
21 Tasavvufun yöntemine farklı bir yaklaşım hakkında ayrıntılı bilgi için bk. Başer, Şeriat ve Hakikat, s. 236244.

22 Serrâc, el-Lüma', s. 101-102, 323-325; a. mlf., İslâm Tasavvufu, s.120, 446-447; Başer, Şeriat ve Hakikat, s. 105-106.

23 Serrâc, el-Lüma', s. 321-362; a. mlf., İs/âm Tasavvufu, s. 443-491; Sağan, "Ebû Tâlib el-Mekkî'nin (ö. 386/996) Düşüncesinde Dinî İlimlerin Gelişimi ve Tasavvuf", 62-63.
} 
Kelâbâzî'nin ise tasavvufu bir din ilmi olarak kabul ettiğini, Kur'ân ve sünneti ana kaynaklar olarak ele aldığını, hal ve makamlar çerçevesinde tasavvufun metot ve âdâbını ortaya koymaya çalışırken zannedilenin aksine tasavvufun da belirli birtakım kurallar üzerine bina edildiğini göstermeye çalıştığını, sûfîlerin Ehl-i sünnet çizgisi ve akâidi üzerine bir yol takip ettiklerini sürekli vurguladığını, böylelikle bir ilim olarak sünnî tasavvufun varlığını ortaya koymaya gayret ettiğini söyleyebiliriz. Bunu yaparken Serrâc gibi tasavvufun konu, gaye ve yöntemini, âdâbını, her din ilmi gibi tasavvufun da sahip olması gereken yetki alanını, bu alana giren şatahat, vecd, semâ', keramet gibi ifadeler hakkında söz söyleme yetkisinin yalnızca tasavvuf ehline ait olduğunu dile getirmektedir. Eserinde kelâmî konulara yer vermek suretiyle Kelâbâzî, hakikati şiar edinmiş tasavvuf ilminin şeriatla çakışmayıp hakikat iddiasında şeriata olan bağıılığını dile getirmiş olmakta ve tasavvufun şeriat-hakikat bütünlüğünü sağlayıp koruduğunu belirtmektedir. Onun bu tavrı, döneminde yaygınlık kazanan ibâhîlik, hulûlîlik, ittihatçılık gibi şeriat dışı gruplara ve tasavvufu reddedenlere karşı bir cevap niteliği taşır. ${ }^{24}$

Kelâbâzî'nin şatahata yaklaşımı hakkında bilgi verecek olursak, onun ehli olmayanlar tarafından anlaşılamayacak tasavvûfî ifadelere yani şatahata eserinde yer vermediğini söyleyebiliriz. O şatahatları sebebiyle eleştiriye maruz kalmış Hallâc'tan ve sözünden açık bir şekilde bahsetmemekle birlikte Bayezid-i Bestâmî, Hallâc gibi zatları büyük birer sûfî olarak kabul etmekten de geri durmamaktadır.25 Zira Kelâbâzî'nin, tasavvuf anlayışını, Hallâc'ın müridi ve sıkı takipçilerinden biri olan Faris b. İsa (ö. 335/947) vasıtasıyla oluşturduğu bilinmektedir. Bu sebeple Kelâbâzî'nin tasavvuf düşüncesinin temelinde Hallâc'ın düşüncelerinin hakim olduğu söylenebilir. Kelâbâzî, Hallâc'ı, söylediği sözden ötürü ayıp ve kusurlu saymamış bilakis mazur olarak değerlendirmiş fakat sekr ve vecd hallerinde söylenen sözlerin tasavvufun özünden sayılmadığını da önemle vurgulamıştır. Buradan hareketle Kelâbâzî̀ye göre Hallâc veya daha genel bir ifadeyle şatah söyleyen sûfîler, vecd halinde söylediği sözlerden ötürü haklı olmasalar da mazurdurlar ve suçlanamazlar. ${ }^{26}$ Onun bu tavrı, tasavvufun, ilk dönemlerinden

24 Göktaş, “Kelâbâzî ve Tasavvuf Anlayışı”, s. 58, 94; Sağan, "Ebû Tâlib el-Mekkî’nin (ö. 386/996) Düşüncesinde Dinî İlimlerin Gelişimi ve Tasavvuf", 56-57.

25 Kuşeyrî er-Risâle'de melâmet, Hücvîrî Keşfü'l-mahcûb'da fütüvvet bahsini ele almazken Serrâc ve Kelâbâzî her iki konunun üzerinde durmamışlardır.

26 Kelâbâzî, Doğuş Devrinde Tasavvuf, s. 21 . Sûfîlerin "rumuzlu" ifade kullanmaları ve sûfî sözlerini en iyi şekilde ancak sûfîlerin anlayabileceği ile ilgili olarak bk. Kelâbâzî, et-Ta‘arruf, s. 88; a. mlf., Doğuş Devrinde Tasavvuf, s. 134-135. Kelâbâzî aynı zamanda vahdet-i vücûd, varlık mertebeleri, Nur-i Muhammedi, insan-ı kamil gibi tasavvuf felsefesine dair konulara değinmez. Ayrıca başkaları tarafından anlaşılamayacak şatahat ibarelerine ve bu ibarelerin yorumlanmasına, Serrâc yer verirken Kelâbâzî değinmemeyi tercih etmiştir. Aslında her iki müellifin de yaptıkları bir iç kontrol olmakla birlikte farklı amaçlar taşımaktadır. Şatahatla ilgili olarak bk. Gazzâlî, Ihyâu ulûmi'd-din, I: 54-57; a. mlf., Ihyâu ulûmi'd-din, I: 94-99; Ebu'I-Hasen Ali b. Muhammed 
itibaren bir iç eleştiri mekanizmasına sahip olduğunu göstermektedir. O, böylece avamın yanlış anlamalarına sebebiyet verebilecek tartışmalı konulara girmeyerek tasavvufu ve mâhiyetini sistemli bir şekilde ortaya koymuş olmaktadır. ${ }^{27}$

Mekkî'nin ise otuz üçüncü fasılda itikâdî konular üzerinde durduğu, burada itikâdî açıdan problemli düşüncelere sahip fırkaları zikredip onlara cevaplar verdiği görülmektedir. 0 kelâmcıların aklî bilgilerinin ve kıyas yoluyla oluşturdukları kitaplarının dördüncü asırda ortaya çıkmaya başladığını, kelâm ehli ile ravi ve nakilcilerin "ulemâ", kussâsın da "ârifler" olarak anılır olduğunu eleştirmektedir. ${ }^{28}$ Kelâmî ve aklî bilgilere dayanarak söylenen sözlerin çoğunun cahiller arasında ilim olarak itibar gördüğünü ve bu kimselerin ilim ile kelâmı temyiz edemediklerini zikretmektedir. ${ }^{29}$ Şatahat ehline yönelttiği eleştiriler ile de tasavvufa bir iç eleştiri yapmış ve tasavvufu sünnî bir zemine oturtmuş olmaktadır. Şatahat sahiplerine yönelttiği tüm eleştirilere rağmen Mekkî’nin bu kimselerin yaşadıkları vecdden dolayı irade bakımından mağlup olduklarını, mağlup olanın ise mazur kabul edilmesi gerektiğini ve vecd halinin her zaman kontrol edilemeyeceğinden hareketle bu hali yaşayanların mazur ${ }^{30}$ görülmesi gerektiği kanaatine sahip olduğunu söylemek mümkündür.

Kuşeyrî ise sünnî tasavvuf anlayışının bir gereği olarak eserinde, tasavvufun sünnî bir çerçevede yer aldığını ortaya koymak amacıyla Eş‘ari akidelerine aykırı gördüğü sûfî sözlerini zikretmemekte, konuları ayet ve hadisler rehberliğinde, sünnî tasavvuf çizgisine uygun olarak ele almakta ve gerekli açıklamaları bu çerçevede serdetmektedir. Tasavvufun, ehli dışındaki kimselerin anlayamayacakları bazı terimlere sahip olduğu görüşüne Kuşeyrî'de de rastlamak mümkündür. Sözgelimi her gruptan âlimin aralarında özel olarak kullandıkları birtakım lafızlar ve terimler olduğunu, bir ilim olarak tasavvufun da ehli arasında böyle terimlerin bulunmasının doğal karşılanması gerektiğini, Allah tarafından sûfîlerin kalplerine yerleştirilen bu terimlerin mânalarının onlara mahsus olup ancak manevî ve rûhî tecrübeler sayesinde öğrenilebileceğini belirtmektedir. Onların bu terimleri kapalı bir şekilde kullanmalarının sebebinin ise kendilerinden olmayanlara karşı

\footnotetext{
b.Ali es-Seyyid eş-Şerif el-Cürcânî el-Hanefî, et-Ta 'rîfât, nşr. Muhammed Sadık el-Münşâvî, Kahire, Dârü’lfazile, 1.bs., 2004, s. 109; Ethem Cebecioğlu, "Şatahat İbarelerinin Anlaşılmasına Doğru: Metodik Bir Deneme", Tasavvuf: IImî ve Akademik Araştırma Dergisi, sayı: 17, yıl: Temmuz-Aralık 2006; s. 7-27; Süleyman Uludağ, "Şathiye", DiA, s. 370-371.

27 Sağan, "Ebû Tâlib el-Mekkî'nin (ö. 386/996) Düşüncesinde Dinî Illimlerin Gelişimi ve Tasavvuf”, s. 62-63.

28 Mekkî, Kûtü'l-kulûb, I: 326; a. mlf., Kalplerin Azığı, II: 100.

29 Mekkî, Kûtü'l-kulûb, I: 328, 331; a. mlf., Kalplerin Azığı, II: 102, 107.

30 Mekkî, Kûtü'l-kulûb, II: 130-131; a. mlf., Kalplerin Azı̆̆ı, III: 222.
} 
kendilerini gizleyebilmek olduğunu düşünmektedir. ${ }^{31}$ Kuşeyrî'nin de eserinde hulûl, ittihat ve panteist anlayışları yansıtacak hiçbir ifadeye yer vermediği, nasları te'vil etmekten uzak durarak gerektiği yerlerde sadece şeriata uygun tefsir yapma yoluna gittiği görülmektedir.

Hücvîrî de Serrâc, Kelâbâzî, Mekkî ve Kuşeyrî'nin bu yöndeki kanaatlerini kabul etmekte, her ilmin kendisine has tabirleri, ıstılah ve sözleri bulunduğunu, bir ilim olarak tasavvufun da bu niteliklere sahip olduğunu, bir ilmin ıstılah oluşturmadaki amacının, ehlinin o ilmin inceliklerini anlamasını kolaylaştırmak, alan dışındaki kişilerden ise bu ilmin sırlarını gizlemek olduğunu belirtmektedir. ${ }^{32}$ Hücvîrî ise te'vilin dinden uzaklaşıp çıkmaya sevk ettiğine vurgu yapmak suretiyle te'vilden uzak durduğunu belirtmiştir. Bu bağlamda o hem nas ve nakle aşırı bağlı olup tasavvufu reddeden Haşeviyye'yi hem de bazı konularda aşırıya giden Hulûliyye'yi eleştirmekten geri durmamıştır. ${ }^{33}$

\section{Sonuç}

Tasawuf, din ilimleri arasında meşruiyet kazanma sürecinde, her ne kadar diğer din ilimleri gibi kendi alanında otorite sahibi olduğunu kabul etse bile, kendisinin diğer ilimlerden ayrı ve bağımsız düşünülmemesi gerektiği noktasından hareket etmiştir. Tasawufun hareket alanı, din içerisindeki manevî ve derûnî meseleleri kapsar. Dinîn manevî alanını konu edinmiş sûfîler, tasavvufun bu yönünü şu üç zümreye göstermek istemişlerdir: Hadis, fıkıh ve kelâm âlimlerine ve ibâhîler gibi sapkın görüşte bulunan kimselere. ${ }^{34}$ Bu açıdan tasavvufun meşruiyet çabasının temelde iki hedefinin bulunduğunu söylemek mümkündür. Tasavvuf öncelikle kendisinin de en az diğer ilimler kadar "meşru" bir alana, kendine has konu, gaye ve yönteme sahip olduğunu ortaya koymayı gaye edinmiştir. İkinci olarak sapkın bazı gruplara, sahip olduğu "hakikat" anlayışının şeriat ile çatışmadığını bilakis onun hükümlerine tabi olduğunu ortaya koyma

\footnotetext{
31 Kuşeyrî, er-Risâle, s. 119 ; a. mlf., Tasavvuf ilmine Dair Kuşeyrî Risâlesi, s. 147.

32 Hücvîrî, Keşfü'l-mahcûb, s. 613-668; a. mlf., Hakikat Bilgisi, s. 426-473. Tasavvuf ilmi özelinde kavramların hicrî III. asra kadar diğer ilimlerin kavramları ile iç içe olduğu, bu kavramların hicrî IV. asırdan itibaren tasavvûfî eğitim ve bilgi-marifet yönüyle ele alınmaya başlandığı müşâhede edilmiştir. Bk. Abdullah Damar, "Tasavvuf Terimlerinin Oluşumu", Tasavvuf IIImî ve Akademik Araştırma Dergisi, sayı: 17, yıl: 7 (2006), s. 161-189, s. 161-164; Sağan, "Ebû Tâlib el-Mekkî’nin (ö. 386/996) Düşüncesinde Dinî Illimlerin Gelişimi ve Tasavvuf", s. 44-46.

33 Hücvîrî, Keşfü'l-mahcûb, s. 501-508, 664; a. mlf., Hakikat Bilgisi, s. 322-327, 460.

34 Serrâc ve Kelâbâzî bu konuda aynı kanaate sahiptirler. Sözgelimi Serrâc tasavvufun din ilimleri karşısındaki meşruiyetini ve dinî yükümlülükleri hafife alan ibâhîlikten farklı olduğunu ortaya koyma bağlamında bu konuya değinirken Kelâbâzî ise Allah'ın farz kıldığı ve Hz. Peygamber'in vacip olarak belirttiği tüm hükümlerden âkil ve bâliğ olan herkesin sorumlu olduğunu, bazı kimselerin dinde üstün nitelikler kazandıktan sonra bu hükümlerin onlardan sâkıt olmasının kabul edilemeyeceğini, bu konularda hiç kimsenin ihmalkâr davranma hak ve yetkisine sahip olmadığını, şeriatla ilgili hükümlerin geçersiz sayılacağı herhangi bir makamdan bahsedilemeyeceğini belirtmektedir. Bk. Serrâc, el-Lüma', s. 25; a. mlf., İs/âm Tasavvufu, s. 22-23; Kelâbâzî, et-Ta'arruf, s. 59; a. mlf., Doğuş Devrinde Tasavvuf, s. 93.
} 
amacı taşımıştır. Tasavvufun, şeriatın hükümlerini geçersiz sayan ibâhî gruplarla karıştırılmasının önüne geçilerek bu gruplardan ayrı değerlendirilmesi de bu bağlamda değerlendirilmesi gereken esas gayelerden biridir. Nitekim Serrâc, Kelâbâzî ve Mekkî gibi tasavvufun tedvin dönemi müelliflerinin eserlerine bakıldığında, ibâhîlerin şeriat hükümleri konusunda çok büyük sorunlara yol açtıkları görülmektedir. ${ }^{35}$

\section{Kaynaklar}

Başer, H. B. (2017). Şeriat ve Hakikat: Tasavvufun Teşekkül Süreci, İstanbul: Klasik Yay.

Cebecioğlu, E. (2006). Şatahat İbarelerinin Anlaşılmasına Doğru: Metodik Bir Deneme. Tasavvuf: IIImî ve Akademik Araştırma Dergisi, 17, 7-27.

Damar, A. (2006). Tasavvuf Terimlerinin Oluşumu. Tasavvuf ilmî ve Akademik Araştırma Dergisi, 17(7), 161-189.

Demirli, E. (2007). Zahiri Ilimlerin Otoritesi Karşısında Tasavvufun Meşruiyet Arayışı. Istanbul Üniversitesi Ilahiyat Fakültesi Dergisi, 15, 219-244.

Tasavvuf Araştırmalarında Dönemlendirme Sorunu: Din Bilimleri ile Metafizik Arasında Tasavvufun Illim Olma Mücadelesi. Nazariyat: Is/âm Felsefe ve Bilim Tarihi Araştırmaları Dergisi, 2(4), 1-29.

el-Mekkî, Ebû Tâlib, Kûtü'l-kulûb fi mu 'âmeleti'l-mahbûb, nşr. Said Nesîb Mekârim, Beyrut, Dâru Sâdır, 2010, 2.bs., I-II.

Kûtü'l-kulûb: Kalplerin Azığı. (çev. M. Tan). İstanbul, İz Yay.

es-Serrâc, Ebû Nasr. (2007). el-Lüma' fi târihi't-tasavvufi'l-Is/âmî. (Haz. Kamil Mustafa Hindâvî).

Beyrut: Dârü'l-kütübi'l-ilmiyye.

el-Lüma: Is/âm Tasavvufu, çev. Hasan Kamil Yılmaz, İstanbul, Erkam Yay., 2012.

Göktaş, V. (2007). Kelâbâzî ve Tasavvuf Anlayışı. (Basılmamış Doktora Tezi). Ankara Üniversitesi

Sosyal Bilimler Enstitüsü Temel İslâm Bilimleri Ana Bilim Dalı, Ankara.

Hücvîrî, Ali b. Osman. (2016). Hakikat Bilgisi. (Çev. S. Uludağ). İstanbul: Dergâh Yay.

Is'ad Abdilhadi Kındil. (1980). Keşfü'l-mahcûb. Beyrut: Dârü'n-nehdati'l-arabiyye.

Kelâbâzî, Ebû Bekir İshâk. (2014). Doğuş Devrinde Tasavvuf: Ta'arruf. (Çev. S. Uludağ). İstanbul: Dergah Yay.

Mahmud, A. ve Sürûr, T. A. (1960). et-Ta'arruf li-mezhebi ehli't-tasavvuf . Kahire: Neşrü'ttürasi's-sûfí.

Kuşeyrî, A. (2014). er-Risâletü'l-Kuşeyriyye, (nşr. Yûsuf Ali Bedîvî) Beyrut: Dâru'I-Yemâme.

Uludağ, S. (çev.). (2014). Tasavvuf IIImine Dair Kuşeyrî Risâlesi. İstanbul: Dergah Yay.

Özköse, K. (2000). Klasiklerimiz III: er-Risâle (İmam Abdülkerim Kuşeyrî, ö. 465/1072), Tasavvuf IIImî ve Akademik Araştırma Dergisi, 4, 202.

Sağan, Merve, "Ebû Tâlib el-Mekkî̀nin (ö. 386/996) Düşüncesinde Dinî ilimlerin Gelişimi ve Tasavvuf", Yüksek Lisans Tezi, Yalova Üniversitesi Sosyal Bilimler Enstitüsü, 2018.

Uludağ, Süleyman, "Şathiye", DiA, yıl: 2010, cilt: XXXVIII, s. 370-371.

35 Serrâc, el-Lüma', s. 376-378; a. mlf., İslâm Tasavvufu, s. 507-510; Kelâbâzî, et-Ta'arruf, s. 19-21; a. mlf., Doğuş Devrinde Tasavvuf, s. 49-51; Kuşeyrî, er-Risâle, s. 449-450; a. mlf., Kuşeyrî Risâlesi, s. 401; Hücvîrî, Keşfü'l-mahcûb, s. 203-213; a. mlf., Hakikat Bilgisi, s. 76-85; Ekrem Demirli, "Zahiri Illimlerin Otoritesi Karşısında Tasavvufun Meşruiyet Arayışı", s. 221-22. 